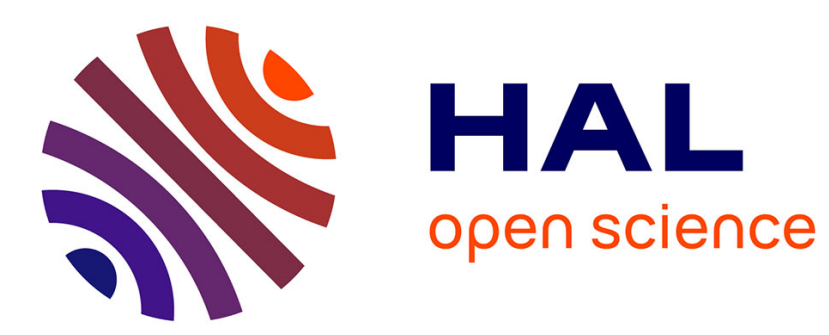

\title{
Towards a Principal-Agent Based Typology of Risks in Public-Private Partnerships
}

\author{
André de Palma, Luc Leruth, Guillaume Prunier
}

\section{To cite this version:}

André de Palma, Luc Leruth, Guillaume Prunier. Towards a Principal-Agent Based Typology of Risks in Public-Private Partnerships. 2009. hal-00419234

\section{HAL Id: hal-00419234 \\ https://hal.science/hal-00419234}

Preprint submitted on 23 Sep 2009

HAL is a multi-disciplinary open access archive for the deposit and dissemination of scientific research documents, whether they are published or not. The documents may come from teaching and research institutions in France or abroad, or from public or private research centers.
L'archive ouverte pluridisciplinaire HAL, est destinée au dépôt et à la diffusion de documents scientifiques de niveau recherche, publiés ou non, émanant des établissements d'enseignement et de recherche français ou étrangers, des laboratoires publics ou privés. 


\section{ECOLE POLYTECHNIQUE}

CENTRE NATIONAL DE LA RECHERCHE SCIENTIFIQUE

TOWARDS A PRINCIPAL-AGENT BASED TYPOLOGY OF RISKS IN PUBLIC-PRIVATE PARTNERSHIPS

André de PALMA

Luc LERUTH

Guillaume PRUNIER

August 2009

Cahier $n^{\circ}$ 2009-36

\section{DEPARTEMENT D'ECONOMIE}

Route de Saclay

91128 PALAISEAU CEDEX

(33) 169333033

http://www.enseignement.polytechnique.fr/economie/

mailto:chantal.poujouly@polytechnique.edu 


\title{
Towards a Principal-Agent Based Typology of Risks in Public-Private Partnerships
}

\author{
Prepared by André de Palma, Luc Leruth and Guillaume Prunier ${ }^{1}$
}

\begin{abstract}
August 2009
Abstract

There is a strong economic rationale for close cooperation between the public and private sectors. This has resulted in a significant increase in the demand for the provision of public services through instruments combining public and private money such as public-private partnerships (PPPs or P3s). We describe these arrangements and explore how they can be analyzed using standard tools in economics (incentives and principal-agent theory). We discuss the implications of our approach in terms of identifying risks that are often overlooked before turining to the optimal risk-sharing between the public and private partners, in particular with respect to information asymmetries in risk perceptions. This allows us to propose a typology of the risks associated with PPPs, where both internal risks (the risks associated with the contract) and external risks (those associated with the project) are considered.
\end{abstract}

JEL Classification Numbers: D23, D73, D82, H54, M38, R42

Keywords: infrastructure financing, public-private partnerships, principal-agent framework, risk classification, transportation infrastructure, value for money

Authors’ E-Mail Addresses: Andre.depalma@ens-cachan.fr; lleruth@imf.org; and prunier.g@gmail.com

\footnotetext{
${ }^{1}$ Respectively at Ecole Polytechnique and Ecole Normale Supérieure de Cachan; the IMF Offices in Europe (EUO); and Ecole Polytechnique. This paper was prepared during the third author's internship in EUO. The authors would like to thank Benjamin Connault, Alain Jousten, Pierre Ewenczyk, Justin Tyson, Emmanuel van der Mensbrugghe, the participants in the High-Level Conference on Fiscal Risks, EUO (Paris, 2008) and participants in the second International Conference on Funding Transportation Infrastructure (Leuven, 2007) for their helpful comments, and J. Dyer for excellent secretarial assistance. The first author would also like to thank the Institut Universitaire de France.
} 


\section{INTRODUCTION}

Historically, the provision of utilities (e.g., telecommunications, air, and rail transport) has mostly been the responsibility of the public sector or of the private sector operating under strict state regulation, often coupled with an agreement to limit competition. In the 1980's, however, the strong wind of deregulation that blew over the United States- long advocated by economists on the grounds of economic efficiency — opened these markets to competition and led to the breakup of many monopolies. For example, local operators were allowed to enter the telecommunications system, a sector that had been the historical monopoly of AT\&T. About ten years later, European markets went through a similar reform. ${ }^{2}$

However, and particularly in Europe and Latin America, there had long been concerns about the excesses that total deregulation or full government ownership could lead to, and this led to the adoption of innovative financing instruments based on a collaboration between the public and the private sectors (see, for example, Välilä, and others, 2005). Substantial rethink of government policies is the root of the political process and, over the years, policies changed, moving from more nationalization to more privatization —and back-in most countries. These shifts were often triggered by changes of governments, but sometimes occurred during the same tenure. In most cases, the debate led to a number of propositions to combine the comparative advantages of the private sector and the public sector. They would no longer be considered as independent (or even competing) actors, but as potential partners who-although fundamentally different in nature-should, when circumstances are conducive to it, collaborate to realize a project and-indeed because they were different in nature-share the risks involved.

In the United States, the appetite for public-private collaboration came later but has accelerated since 2005. The 2004 U.S. Department of Transportation (USDOT, 2004) report to Congress on public-private partnerships (PPPs, or more recently P3s) was a first attempt to provide U.S. Congress and interested states with information related to PPPs and other similar instruments but, at that time, PPPs were often not even considered as an alternative to either private sector or public sector involvement. The situation has changed dramatically since then and the 2008 update of the report refers to an "unprecedented use of long-term, concession-based public private partnerships in the US" (U.S. DOT, 2008, p. 6). ${ }^{3}$ One of the reason is, as in other countries, the failure of traditional approaches to transportation and other large projects. For example, the U.S. Government Accountability Office (the "GAO”) has identified a number of "high risk" programs that are providing a critical service to the public and involve substantial resources but have failed to deliver. For such programs, the GAO recommended that U.S. Congress and U.S. Administration consider alternative options, including PPPs (see GAO, 2007). By far the most innovative use of PPPs has come in 2009

\footnotetext{
${ }^{2}$ For example, the telecommunications operator in France (France Telecom) lost its monopoly in 1999.

${ }^{3}$ The U.S. DOT 2008 Report (p.11) goes on to argue that "all levels of Government in the United States are looking for innovative and creative ways to reform the traditional approaches to transportation funding and procurement and PPPs are an increasingly preferred alternative.”
} 
from the Treasury Department (in collaboration with with the Federal Deposit Insurance Corporation and the Federal Reserve) when Mr. Geithner proposed the Public-Private Investment Program (or PPIP) initiative to "address the challenge of legacy assets, ... repair balance sheets throughout our financial system and ensure that credit is available to the households and businesses, large and small, that will help drive us toward recovery."4 At this stage, it is premature to assess whether it will be a success, but its magnitude (the scheme is expected to use $\$ 75$ to $\$ 100$ billion in capital from various sources, to generate $\$ 500$ billion and up to $\$ 1$ trillion over time - in purchasing power to buy legacy assets) and originallity certainly make it a an important milestone in the development of PPPs. The private sector and a number of think-tanks have also taken a deep and positive interest in PPPs (see, for example, Stark, 2008 and various reports by the Reason Foundation, such as Gilroy, and others, 2008). ${ }^{5}$

Indeed, there is a strong economic rationale for close cooperation between the public and the private sectors, especially when: (a) the public sector wants to leverage its limited resources by using taxpayers money as a catalyst for private funding: more projects can be completed and the provision of services increases as a result; (b) the public sector wants to avail itself of the savoir-faire and the skills of the private sector, which could provide better management in a number of situations; and (c) the private and the public sectors wish to limit their exposure to the risks involved in large-scale projects (of public interest) by allocating these risks - depending on who is best able to bear them-among themselves or to a third party.

The first two points are standard and will be addressed in section II. To briefly elaborate on the third point - a critical aspect of this paper-it should be noted that both the private firm and the public sector have an intrinsic preference for transferring risks to the other party. Clearly, the public sector will have an interest in passing on risks to the private sector operator or to an insurance company in most circumstances. That may not always be possible, however, and there are situations where the partnership may benefit if the private firm shares some of the risks with the public sector, for example when the company is at an early stage of development and therefore does not have easy access to financial markets (the risk premium is just too high), or when some of the risks involved cannot be insured or adequately diversified by the private firm (e.g., for macroeconomic shocks or for a liquidity risk caused by a credit crunch). More generally, over the past few decades, the literature has identified a number of risks associated with large-scale projects and these include the risks associated with fluctuations in demand, sudden changes in the costs of production factors, setbacks in completion time, and the risk of competing programs sponsored by competitors (and which could fully or partly replace those developed by the firm). Obviously, as the

\footnotetext{
${ }^{4}$ See U.S. Department of the Treasury (2009).

${ }^{5}$ Arguably, there had already been some form of PPP undertakings in the US earlier, in particular in the context of the privatization of water utilities in the late eighties and with toll roads in the nineties.
} 
public and the private sectors decide on the principles guiding a possible partnership, a key question is how the risks should be shared among them. ${ }^{6}$

Demand for the provision of public services through instruments combining public and private money has thus led to the development of a family of contractual vehiclescommonly referred to as PPPs - that facilitate this form of cooperation and have become increasingly widespread, both in developing and rich countries. ${ }^{7}$ Yet, while providing scope for deriving substantial benefits from cooperation, including for sharing risks more efficiently, PPPs also add a new type of risks: those associated with the contractual arrangement (as opposed to those associated with the project) which were often ignored but typically borne by the taxpayers. The purpose of this paper is to review both sources of risks and propose a typology that facilitates their assessment and their allocation to the party best able to handle them.

The paper is organized as follows. In Section II, we discuss the recent development of PPPs. In Section III, we argue that the principal-agent model is a useful framework to look into PPPs and lay the ground for a more thorough analysis of the various sources of risks involved. In Section IV, we look at the implication of our analysis on the nature of risks associated with PPPs and discuss some key concepts related to information asymmetries. In Section V, we propose the typology of risk in the PPPs and the results are summarized. Conclusions are presented in Section VI.

\section{The DeVELOPMENT OF PPPS}

The concept of PPP refers to contractual arrangements covering a long time period (typically more than 20 years) by which public authorities assign to private operators the fulfilment of a mission of public interest. The standard procedure can broadly be defined as follows: in order to bid for a contract proposed by a government, a private group of interest (consortium) creates a legal entity, so-called Special Purpose Vehicle (SPV) with a mission to build, maintain, and operate the assets (or a combination of these). The consortium can, for example, include a building company, a maintenance operator and a group of financial lenders. The SPV is entitled to sign contracts with governments and other contractors or subcontractors. Its modalities can vary widely, reflecting the nature of the specific mission and the objectives of the government. ${ }^{8}$ Even the structure of SPVs varies. For example, the

\footnotetext{
${ }^{6}$ Although combining different kinds of risks may increase or decrease the overall risk, we do not focus on this aspect and explore it in de Palma and others (2009). For a general reference on risks in the construction industry, see Akintoye, and others (2003).

${ }^{7}$ There are several definitions of PPPs depending about the scope of the contract, but a good "narrow" definition is provided by Irwin (2004): "privately financed projects in which the government either is the main purchaser of the output under a long-term contract or supplements user fees with subsidies or guarantees.” See also section 2 of this paper for a more general definition of PPPs, or Schwartz, and others (2008).

${ }^{8}$ In the specific case of road infrastructures, for example, the government could pay shadow tolls to the manager, on behalf of road users.
} 
distinction often made between outsourcing parts of a program to building and exploitation companies, versus finding financial partners to support the whole project is somewhat artificial, as many programs use an integrated scheme of the DBFO (Design, Build, Finance, Operate) type. These developed in the United Kingdom, for example-under the umbrella of the Public Finance Initiative (PFI) in the 1990's - because the authorities were pressed by the need to respect the Maastricht criteria (which limits the budget deficit as well as the level of public debt) while meeting the increasing demands for investment in schools, hospitals, transport and public buildings, severely affected by chronic underfunding. The PFI can broadly be seen as the vehicle developed by the United Kingdom to encourage PPP projects where most aspects, from conception to management, including funding, are under the responsibility of a single operator (company or consortium). ${ }^{9}$

Gradually, the desire for private sector involvement has extended beyond the construction or operation of the asset. For example, an increasing number of private financial companies have specialized in helping public institutions raise capital and design schemes to recover user fees, even in cases where the possibility to do so would have seemed remote a few years ago. ${ }^{10}$ Nevertheless, there are bounds to the expansion and the list of potentially profitable public infrastructures remains limited (say water and energy production and supply, garbage collection, large seaports and airports) by the scope to recover costs from the user. ${ }^{11}$ This creates a difficulty when the authorities seek to involve a private sector operator, understandably reluctant to devote resources to finance or operate public infrastructure when fees are uncertain. ${ }^{12}$

More generally, governments look at PPPs as a means to leverage taxpayers money and ensure long-term financing for programs that would occupy too much fiscal space in their annual budgets if they had to be fully financed by public funds (as mentioned above, this was the case in the United Kingdom when the PFI was launched).$^{13}$ Although definitions vary and in spite of the risks involved (which are discussed in the next section), country experience

\footnotetext{
${ }^{9}$ There was also some soul-searching in the United Kingdom about the respective roles of the public and the private sector after the massive wave of privatization started under Prime Minister Thatcher in the early 1980’s.

${ }^{10}$ See de Palma and Prigent (2008) for an example of financial instruments to hedge against environmental events.

${ }^{11}$ This includes social considerations. For example, there are countries where recovering the costs of providing water is socially difficult to accept.

${ }^{12}$ But risks are not limited to fees. The lack of a single, recognized accounting framework for PPPs can also trigger difficulties, in particular with regard to the valuation of assets. For example, the value of transport infrastructures for oil and electricity (pipelines and high-voltage lines) is opened to various, somewhat arbitrary, accounting revision procedures, leading to conflicts between the owner and the user of the asset. These points will be discussed further in the rest of the paper.

${ }^{13}$ Governments may also use PPPs, at least in theory, as a way to integrate infrastructure development with service provision so as to better align incentives for adequate design, construction and maintenance.
} 
suggests that PPPs have generally been successful, although there have also been significant failures. ${ }^{14}$

In the United States, where experience is relatively recent, it is difficult to assess the success of PPPs since some of the risks typically associated with them could still materialize. Aware of this, and while actively supporting PPPs, the U.S. DOT has also issued various recommendations in the form of public policy considerations and covers issues likely to arise depending on the type of PPPs that is adopted. Nevertheless, U.S. DOT stresses the benefits of the approach and this view is clearly shared by others. ${ }^{15}$ For example, in a recent testimony to the Massachusetts Joint Committee on Transportation (December 3, 2008), Gilroy cites a number of PPP successes and concludes that the overarching recommendation for the State of Massachusetts should be to encourage "the aggressive pursuit of private sector participation in transportation services" (through PPPs).

Elsewhere, experience has been longer and well-documented in cases that include Australia, Chile, and the United Kingdom. ${ }^{16}$ It is therefore not surprising that the European Commission largely supports the PPP initiatives, and launched a wide-scale public consultation through the Green Paper adopted in April 2004. ${ }^{17}$ This initiative has now been translated at the level of the European Union into more funds channeled through the Loan Guarantee Instrument for the Trans-European Transport Network Projects (LGTT), which consists of a European Investment Bank (EIB) guarantee for subordinated debt in form of a stand-by liquidity facility to be provided by commercial banks, thus providing security for the initial traffic revenue risk over the first 5-7 years of a project's operation. It is designed to provide significant additional risk capital to increase private sector investment in the Trans-European Network (TEN) in the transport sector. The LGTT has a capital commitment of EUR

\footnotetext{
${ }^{14}$ One of these is the Road Concession Program in Mexico in the 1990's that was plagued by cost overruns, revenue shortfall, and a massive increase in toll fees (see Cuttaree, 2008).

15 The 2008 U.S. DOT report states that "long-term, concession-based PPPs for highway projects have been implemented over the last three years, and the tangible benefits that these projects provide are becoming increasingly clear ...” (p. 8.).

${ }^{16}$ In the State of Victoria, for example, a detailed and explicit policy on PPPs (Partnerships Victoria) has been developed, with an emphasis on Value for Money (VFM) and the public interest (see Fitzgerald, 2004). As of 2007, 16 Partnerships Victoria projects have been contracted worth around US\$4.5 billion in capital investment. Since 2002-03, Partnerships Victoria projects have accounted for approximately 10 percent of annual public asset investment commitments (see Partnerships Victoria, 2004, and http://www.partnerships.vic.gov.au). In the United Kingdom, a report by Arthur Andersen (2000) estimated cost savings due to the PFI at 17 percent, with two thirds of the PFI projects delivered on time and with no cost overruns (see also the UK National Audit Reports, 2000, 2003, 2004 and 2006). Chile is particularly interesting with 36 PPPs (US\$5.5 billion) mostly in the areas of rural electrification and telecommunications. See also Estache (2005) for a discussion of PPPs in developing countries.

${ }^{17}$ See EC COM (2004) 327.
} 
1 billion (half from the EC and half from the EIB) aimed at increasing the number of large public programs in EU member states relying on PPPs. ${ }^{18}$

\section{Risk-Sharing, Asymmetry of Information, AND Perception Biases}

Although experience with PPPs has generally been positive, it has also led to costly disappointments. A frequent occurrence has been the exaggerated exposure of the government to risks, usually in the form of hidden liabilities. By definition, economic efficiency requires that risks be evaluated and shared optimally between the partners: i.e., assigned to the state, to the private sector operator, or to an outside insurer. ${ }^{19}$ There is no clear-cut way of sharing risks, but the literature suggests that most of them (not all) can be transferred to the private sector, whereas the state should essentially remain in charge of managing acts of nature (e.g., a volcanic eruption) and the fiscal risks. ${ }^{20}$ In this context, fiscal risks are those related to weaknesses in the legal and institutional frameworks or in the design of policies that affect the project. Obviously, these risks to the project are related to decisions of the state. By failing to correct institutional weaknesses, the government will inevitably retain risks that, objectively, should be transferred and it will therefore have to bear their possible costs (see for example, IMF, 2004, and Hemming and others, 2006). ${ }^{21}$ In the table below, costs overruns associated with the construction (and caused by poor evaluation) are assigned to the private sector. However, these should not be associated with other costs overruns — which tend to plague large infrastructure projects—occurring during construction and are caused by "acts of nature" that are not insurable. Those typically become the responsibility of the state. ${ }^{22}$

We present below a possible risk-sharing table (by no means universal, but in line with many other studies) organized along the various phases of the partnership and adapted from a number of sources (see Table 1 ). ${ }^{23}$

\footnotetext{
${ }^{18}$ See EIB (2009). For the period 2007-13 alone, the investment needs in TEN infrastructures are expected at some EUR300 billion in total. For a description of trends in PPP investments in Europe, see Välilä (2005).

${ }^{19}$ And if the cost of insuring against a certain risk is too high, the project should be dropped, as we shall stress later.

${ }^{20}$ See, for example, Hemming and others (2006).

${ }^{21}$ Note that economists in the field of organization theory would argue that organizations can never be perfect (and should not be for cost efficiency reasons), which implies that some such risks will never be transferrable.

${ }^{22}$ Sharing risks is an important component of the PPIP which is based on three basic principles that are very much in line with the analysis presented in this paper: 1) maximizing the impact of each taxpayer dollar; 2) sharing risk and profits with private sector participants; and 3) using the private sector (as an agent) to find out the true price of the loans and securities targeted by the program. See U.S. Department of the Treasury (2009).

${ }^{23}$ The table proposed here is inspired from various sources. Some present risks in a linear fashion (the public and private sectors fully assuming certain risks and gradually sharing others) (see, for example, Stark, 2005), while other authors present risks in a table (e.g., the Dexia group or the French Direction Générale des Routes, 2005). See also: http://www.equipement.gouv.fr/IMG/pdf/texte_cle283671.pdf). Note that we have not included
} (continued...) 
Table 1: A Basic Matrix for Risk-Sharing in PPPs

\begin{tabular}{|c|c|c|}
\hline TIME & Public Sector & $\begin{array}{c}\text { PRIVATE SECTOR } \\
\text { (PPP OPERATOR OR OUTSIDE } \\
\text { INSURANCE) }\end{array}$ \\
\hline & Project specifications & \\
\hline & & Concept, construction \\
\hline & & Operation, maintenance \\
\hline & "Act of nature” non-insurable & "Act of nature" insurable \\
\hline & Demand for minimum (social) output & \\
\hline & & Financing cost \\
\hline & Resi & \\
\hline
\end{tabular}

In the rest of the paper, we argue that this type of analysis misses several critical elements of PPPs that impact on how risks affect these partnerships and this is because:

- there is an asymmetry of roles and of information between the two partners of the PPPs; and

- there are perception biases that complicate the rational evaluation of risks and exacerbate the impact of information asymmetry.

\section{A. Asymmetry of Information}

First, the allocation of risks between the PPP partners cannot rely on the implicit assumption that the public and private sectors are on an equal (or horizontal) footing in the partnership. This is indeed not the case since the private sector operator is granted a contract by the public sector in order to undertake an infrastructure project, which implies that there is a hierarchy. This hierarchy has important implications on the risks affecting PPPs because delegating responsibility to the private sector (through a contract) adds a set of risks distinct from those associated with the project. Yet, although different in nature, it is generally difficult for the government to disentangle both risks because the private operator usually has more information than the government, in particular with respect to:

- its ability to carry on the tasks and the nature of its actions: Typically, the authorities cannot determine with accuracy the competence or skills of the firm (it may be new on the market or have a mixed reputation, for example). The principal- 
agent theory, which we will discuss in the next section, models this by assuming that the level of effort made by the firm is not observable. However, it is possible for the state to take a number of (costly) measures to learn about (and change) the agent's efficiency; ${ }^{24}$ and

- the characteristics of the project and the state of nature: The firm will generally be better informed about the project than the authorities, both on the construction risks (e.g., is the land stable, has the cost of input gone up or will the concrete last?) and on external factors that could hamper or facilitate its implementation (weather conditions).

More formally, the authorities can observe the output of the PPPs but, in case of low output, cannot determine whether it corresponds to a low level of effort on the part of the private company or to a bad state of nature. Thus, when signing a contract with a private operator, the state must attempt to protect itself by including a number of clauses (controls, penalties) that will limit (but generally not entirely prevent) the ability of the private operator to indulge in corruption.

Second, even though a PPP involves a hierarchical arrangement, there are also risks for which information could possibly be symmetric between the players, but where the implications are not. Typically (and unfortunately), the materialization of such risks has often led to substantial costs for the taxpayers. To illustrate this, let us consider the case of an exchange rate guarantee included in a PPP contract in order to protect the agent from "excessive" rate fluctuations (i.e., if the rate goes beyond or below certain thresholds, the agent is entitled to a compensation). Let us also assume that the probability of going through the thresholds is so low (and the time during which it is outside the two bounds so short) that the principal decides to neglect the risk, even if the level of compensation is possibly very high (and perhaps hard to quantify), or includes a clause that is not adequately covering an identified risk. ${ }^{25}$ Some countries have had this experience:

- in Spain, private toll road operators unexpectedly called US\$2.7 billion of exchange rate guarantees (in the 1970's and the 1980's) when the currency unexpetedly and only briefly went through a threshold;

- in Indonesia, an exchange rate guarantee of US\$260 million was called in the context of an electricity project (2001). ${ }^{26}$

\footnotetext{
${ }^{24}$ For example, by appointing an independent auditor or expert. However, it does not affect the basic idea that the agent and the principal have conflicting incentives in terms of transparency: the agent tries to blur the signal, whereas the principal tries to clarify it.

${ }^{25}$ In a paper reviewing various aspects of contract design theory and its application to PPPs, Dewatripont and Legros (2005) also point out that endogenous risks (associated with a PPP contract) can potentially be very high.

${ }^{26}$ These figures can be found in Irwin (2004).
} 
While it would be tempting to argue that such events could have been adequately covered by the PPP contract, it should be noted that the literature on cost-benefit analysis often does not properly take risk into account and (at best) models it by making assumptions on the risk aversion that are not realistic (in the sense that they do not correspond to the agent's perception) ${ }^{27}$ Since the agent acts on the basis of his or her perceptions, neglecting this can have dramatic implications, in particular in terms of the optimal risk-sharing or on the valuation of an insurance.

\section{B. Perception Biases}

Thus, subjective perceptions can play a critical role in the way risks are assessed by the partners and therefore on how they will insure against them. Typically, economic experiments suggest that events that have a very low probability of occurrence (close to zero) are (subjectively) overestimated by agents. Conversely, events with a high probability of occurrence (close to one) are subjectively perceived as having a lower probability (see Kahneman and Tversky, 1979). To illustrate this, consider a decision-maker facing a lottery $(x, p)$, where $x$ represents the outcome that occurs with probability $p$. The utility derived by the agent is denoted by $U(x)$, where $U($.$) represents the decision- maker's utility function.$ The objective probability $p$ is perceived differently by the agent who behaves as if a probability transformation (or distortion), denoted by $w($.) was applied to $p$. The transformation $w($.$) is strictly increasing over the interval [0,1]$ with $w(0)=0$ and $w(1)=1$ (when an event never occurs and always occurs, there are no distortions). In short, economic experiments suggest that, instead of evaluating the lottery $(x, p)$ by $p . U(x)$, the agent values it as $w(p) . U(x)$. In other words, $p$ corresponds to an objective probability and $w(p)$ to a subjective probability. The objective probability is unique while the subjective probability of the experts, the agent, the principal and, more generally, of the citizens, may all differ.

In Figure 1 below (from Kahneman and Tversky, 1979), we represent an example of subjective probabilities $w$ as a function of the objective probabilities $p$.

Perception biases are not only limited to the probability of occurrence. They also apply to the scale of the incidents (or the outcome), in particular when a major risk materializes. Once again, economic experiments suggest that "society" seems less able to tolerate major disasters than repeated incidents, even when the total number of victims is the same in both cases. This is referred to in the literature as the aggregation bias. As shown by Lichtenstein and others (1978), a curve similar to Figure 1 occurs when citizens are required to evaluate the number of deaths due to familiar causes (small pox vaccination, electrocution, tornado, flood, pregnancy, homicide, heart diseases, etc.): when the number of fatalities is low (and even when the event occurs repeatedly), citizens overestimate it. When it is large, they underestimate it (see also Olson, 1965).

\footnotetext{
${ }^{27}$ In this context, agent can correspond either to the state or to the private firm, but this will change in the next section where we will refer to the state as the principal and the private firm as the agent.
} 
Figure 1. Perception Biases

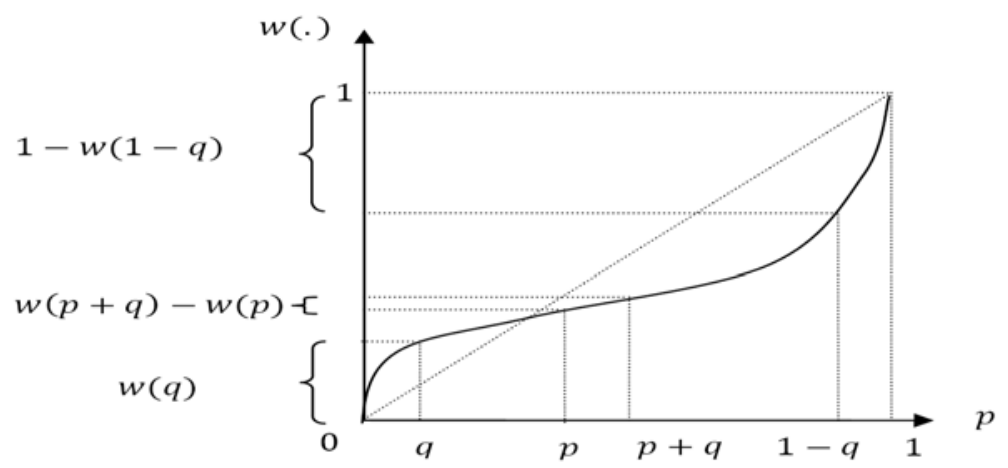

The discussion above suggests that it is sometimes hard for economic agents to fit their perception of risks into a standard normative analysis (expected utility theory) and a more descriptive approach (inspired by experimental data and that developped into the so-called nonexpected utility theory) is sometimes privilieged although it opens the door to biaises (in particular, in an experiment, results can be affected by the way the questions are framed). For the purpose of our analysis of PPPs, however, the discussion leads to two conclusions that are particularly relevant:

- It is difficult to include in a PPP contract clauses that will cover uncertainty (as opposed to risks), as empirical economic theory suggests and as a number of countries have experienced. Thus the cost of such extreme events materializing is likely to be borne by the taxpayers (as it should be);

- Even if all efforts are made to include in the contract provisions to insure against the risks of extreme events and base them on the best possible economic analysis, making these provisions public (a recommendation generally perceived as full of merit and indeed routinely made for the sake of transparency) constitutes a major risk for the authorities as the public at large may have a different perception of the probability associated with dramatic events and blame the government for mismanagement. For a discussion of this and related issues, see Best (2005) and Furman and Stiglitz (1998).

\section{A Principal-Agent ApProach to PPPs}

Our approach to PPPs is based on the theory of incentives and principal-agent (P-A) developed by Laffont and Tirole (1993). In a nutshell, incentive theory describes the behavior of a boss (the principal) who cannot accurately monitor the productivity of his or her employee (the agent). The principal can, however, introduce a set of incentives in order to increase the agent's efficiency. Such incentives are costly; and some are working better than others (see Section IV). 
These considerations will help us propose a typology of risks to help assess better and allocate risks.

The key assumptions underlying a P-A framework are well known:

- Information is asymmetric between the parties: in general, the agent (the private sector operator) has more information about its own actions (moral hazard) and the so-called "state of nature" (adverse selection); and

- The agent pursues its own interests, which may run contrary to those of the principal (the state). ${ }^{28}$

These assumptions are very similar to the basics of a PPP contract, with the government acting as the principal and the private sector as the agent. When the government instructs the private sector to perform a certain task on its behalf, it tries to negotiate a contract that will stipulate the relevant parameters, including the nature and quantity of output; specific benchmarks and timing; and the tools by which the government will control the performance of the private sector operator. The framework can be represented as follows:

Figure 2: The Principal-Agent Framework

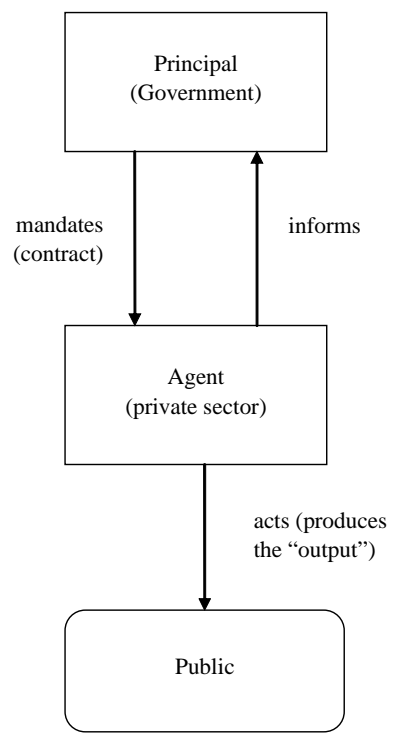

It is not surprising that many of the questions raised by economists working on principalagent models find an echo in the concerns of PPP specialists. ${ }^{29}$ In particular, in situations

\footnotetext{
${ }^{28}$ The P-A framework would also allow us to look at the government as an agent for the general public. This would be a useful approach as well since there have been several documented cases of officials bribed by the private sector to obtain approval for a project (PPP or not) that was not in the public interest.
} 
where incentives cannot be perfect, they lead to moral hazard issues on the part of the agent. We alluded to this conflict of incentives between the players earlier, and the principal must try to reduce these moral hazard issues as best it can, for example by using an auditor to find out the true state of nature. ${ }^{30}$ More generally, the best results for the principal and/or the agent, just like in a PPP, would be obtained with: ${ }^{31}$

- A fully specified, enforceable contract between the government and the firm;

- Stable terms of contract over time;

- Measurable output indicators, and service delivery that can be monitored; and

- Credible punishment in case cheating is proven.

Here, we are concerned by the P-A approach as a framework to look at risk-sharing. However, the model has also recently been thoroughly examined by economists looking at the theoretical foundations of PPPs. For example, Benett and Iossa (2006) and Martimort and Pouyet (2006) use incomplete contracts theory to consider the conditions under which it is optimal to bundle building and service procurement (one important issue in PPP arrangements) and find interesting results. ${ }^{32}$

- The key finding for our purpose is that if, at the end of the contract, the builder owns the asset, it has an incentive to invest more in the design and the building. This has another interesting consequence: automatic transfer of ownership at the end of the contract transfers the risk of the residual value from the private to the public sector. ${ }^{33}$

\footnotetext{
${ }^{29}$ On the P-A model, see Laffont and Tirole (1993), Kofman and Lawarrée (1993), and Kofman and Lawarrée (1996). For applications to PPPs, see the special issue of the International Journal of Industrial Organization (2008). Some of the papers appearing in the special issue are discussed below. Earlier work on the link between PPPs and P-A theory include Vickerman (2004), Bentz and others (2003) and, more indirectly perhaps, Hart (2003) and Hart and others (1997).

\begin{abstract}
${ }^{30}$ Moral hazard occurs when the agent (who has more information about its actions or the state of nature) behaves inappropriately from the perspective of the principal (who has less information). Technically, the state of nature can be high or low. If it is high, as we have already indicated, the agent may be in a position to convince the principal that it is low so that it will be satisfied with the level of output normally associated with a low state of nature. This may be at the advantage of the agent if the transfer it receives, minus the effort and inputs it puts in, is comparatively higher.
\end{abstract}

${ }^{31}$ All these themes are reminiscent of transaction costs theory (e.g. Williamson, 2002, or even Coase, 1937 and 1992) and complete the various elements of risks that we have identified using our framework. For the legal aspects, see for example Demsetz (1967).

${ }^{32}$ For a more complete discussion of some key theoretical foundations of PPPs, see Leruth (2008).

${ }^{33}$ Although not directly related to our purpose, collusion is one aspect of corruption that can also occur in PPPs. Martimort and Pouyet (2006) show that collusion can be avoided by giving financial incentives to the public sector so that it is no longer in its interest to collude. Obviously, this reduces social welfare, so that the costs to society may be so high that collusion cannot be avoided.
} 
In addition, like all models, the principal-agent has a limited scope and is based on a number of assumptions that constraint its ability to serve our purpose in proposing a typology of risks for PPPs. Identifying these limitations is critical to complete the typology.

- The main limitation is that the model does not allow for cheating by the principal and does not allow for a reaction from the ultimate recipient of the service (the public in the graph) ${ }^{34}$ We must remove this limitation because experience shows that private sector operators involved in PPPs have been subject to abusive behavior by the state with little recourse if any (for example, nationalization or the sudden cancellation of a contract).$^{35}$ In a sense, after having stressed the hierarchical nature of the relationship, we must acknowledge that there is some symmetry with respect to the desire of cheating the other partner. This dimension is therefore included in the typology.

\section{PPP RISKS AND A TYPOLOGY}

Many of the risks in a PPP are intrinsic to the project, i.e., these risks exist independently of the financial and operating structure of the project (e.g., demand risk, construction). However, it follows from the discussion above that other risks are associated with the specific PPP contract arrangements, in particular with the "vertical" nature of the partnership between the principal and the agent. This key dimension is typically neglected in typologies of risks and hence, our table (Table 2 below) separates "project” and "partnership" on the horizontal (upper) axis.

Regarding the second axis, the relevant dimension is clearly the nature of the asymmetry of information that exists between the partners. This asymmetry is relevant both for the partnership and the project and indeed, as we have already seen, the P-A model points to the difficulty for the principal to disentangle an inefficient agent operating in a good environment from an efficient one operating in an adverse environment. But while the P-A model only allows for an agent better informed than its principal (and thus, it is the principal who essentially faces the risks of the partnership), we have discussed above the very real possibility that the principal could hold more information than the agent (and thus, the agent may equally face risks associated with the behavior of the principal). In addition, the conflicting incentives of both players to distort the facts further exacerbates the perception bias that will affect each of them individually, and we have shown in Section III that this plays an important role.

To summarize the case of asymmetric information, the risks generated by the bad behavior of one player (agent or principal) are generally borne by the other (who is also affected by a

\footnotetext{
${ }^{34}$ That is why the arrow in the graph going from the pubic to the government is dotted. In a P-A framework, this would require the principal to be itself the agent of a superior principal (the public, or perhaps the assembly) and, to our knowledge, this has not been done in the theoretical literature.

${ }^{35}$ See Laffont and Tirole (1993) for various examples. See also Dewatripont and Legros (2005) who devote a section of their paper to political risks.
} 
perception bias): for instance, the public sector bears the ability risk and the agent that of the public sector changing key modalities of the contract halfway through the project. One possible exception to this rule is the protection extended to the agent by public regulatory bodies (including the justice system). Although such bodies are part of the public sector, they usually enjoy a level of independence that-in good circumstances-makes them able to punish the government if it behaves improperly. Obviously, this only applies in countries where regulatory bodies are strong, and the rule of law is binding.

In addition, the theory of incentives suggests that a player should bear the risks linked to the aspects of the project or the partnership over which it has more information or should find an outside insurance company ready to cover that risk. Clearly, if neither the agent nor an insurance company is willing to do so, the project should be dropped.

Obviously, the second axis also includes the case of symmetric information. In that case, there is no added value to a single agent bearing all the risks when information is symmetric: the risks should be shared between the principal and the agent, depending on their relative risk-aversion or on their portfolio of activities. ${ }^{36}$

In the typology, we have reflected our discussion in Section III.B. by leaving opened the possibility that either the public sector or the private sector could face some risks originating from perception biases. Most often, these would be related to a reaction by voters to information on a PPP made public by the government who would then have to face the backlash. But there are also cases where the private sector faces the backlash from the population, especially from those living in the area of the project. ${ }^{37}$

The residual value risk remains a complex issue to tackle, due to the difficulty in assessing the value of the asset at the end of the contract. ${ }^{38}$ Computing residual values is subject to

\footnotetext{
${ }^{36}$ It does not follow from this discussion that we necessarily advocate that more resources should be spent on collecting more information, even if that information is made available to both parties. Indeed (and unfortunately), it is not necessarily the case that more information raises welfare, even when information is symmetric. Consider the simple and somewhat extreme example of two players, $\mathrm{P}$ and $\mathrm{A}$, where $\mathrm{P}$ is riskneutral and A is risk-averse. Assume also that A faces a possible source of risk (ex ante). Clearly, A should transfer all risks to $\mathrm{P}$ at a contingent price (which can be done as long as markets are complete and $\mathrm{P}$ willing to pay). However if, at the beginning of the process, the state of nature (concerning the source of risks) is revealed to both players, then markets will no longer be complete (one cannot short-sell a crop when one knows that the meteorological conditions will be terrible!). In that case, the risk cannot be fully transferred from A to $\mathrm{P}$ and utility deteriorates. This is yet one more case where more transparency is not necessarily welfare-enhancing.

\begin{abstract}
${ }^{37}$ Such considerations are at the root of initiatives (some also a collaborative effort between the public sector and the private sector) such as the Extractive Industries Transparency Initiative (EITI), which "aims to strengthen governance by improving transparency and accountability in the extractives sector. The EITI sets a global standard for companies to publish what they pay and for governments to disclose what they receive." (EITI, 2009; www.eitransparency.org). The aim is to provide clear and transparent information in order to limit the scope for misinterpretation either by the population or by interest groups with their own agendas.
\end{abstract}

${ }^{38}$ Note that the residual value appears in the list of risks in Table 1 . This is because time had been selected as the main dimension and the "residual value" risk thus appears at the end. However, in our framework, time does not need to appear.
} 
debates because they depend on a number of critical hypotheses (which are sometimes questionable, such as the cost of waste materials, the discount rates, etc.). We have also pointed to the issue of asymmetry of information in the context of our discussion of the P-A model and stressed that the risks can be transferred from the private sector operator to the authorities. Often, the residual value will therefore need to be assessed on a case-by-case basis.

Finally, note that our analysis has allowed us to allocate a number of risks usually not explicitely identified in existing practice in risk allocation in PPP projects. Most of these correspond to risks that should be borne by the private sector, but not all. In particular, our framework has led us to include in Table 2 the renegotiation risk as well as the role of the legal and regulatory framework in assigning political risk.

All these considerations are summarized in the following table. 
Table 2: Typology of Risks in PPPs

\begin{tabular}{|c|c|c|c|c|c|}
\hline & Project & Riskbearer & Partnership & \multicolumn{2}{|c|}{ Riskbearer } \\
\hline $\begin{array}{l}\text { Private information of } \\
\text { the firm (with } \\
\text { perception bias by the } \\
\text { government) }\end{array}$ & $\begin{array}{l}\text { - Construction risks not linked to } \\
\text { the state of nature } \\
\text { (cost overruns, delays, poorly } \\
\text { designed asset) } \\
\text { - Maintenance risk } \\
\text { - Performance risk } \\
\text { (poor quality of operations once } \\
\text { the project is completed) } \\
\text { - Demand risk } \\
\text { (due to poor performance of the } \\
\text { private operator) }\end{array}$ & Private & $\begin{array}{l}\text { - Ability risk } \\
\text { (the private operator may not be able } \\
\text { to manage efficiently the project) } \\
\text { - Renegotiation risk } \\
\text { (expropriation of the government by } \\
\text { renegotiation initiated by the private } \\
\text { operator) }\end{array}$ & & Public \\
\hline $\begin{array}{l}\text { Symmetric information } \\
\text { (with possible } \\
\text { perception bias by all } \\
\text { parties, including the } \\
\text { voters) }\end{array}$ & $\begin{array}{ll}\text { - } & \text { Financial risk } \\
\text { (inflation, interest rate and } \\
\text { exchange rate fluctuations) } \\
\text { - } & \text { Natural disasters } \\
\text { (storm, flood, hurricane) } \\
\text { - } \\
\text { Macroeconomic shocks } \\
\text { (recession, international crisis) } \\
\text { - Demand risk } \\
\text { (due to the macroeconomic } \\
\text { situation) }\end{array}$ & $\begin{array}{l}\text { Public } \\
\text { and } \\
\text { Private }\end{array}$ & $\begin{array}{l}\text { - Residual value risk } \\
\text { (uncertainty about the value of the } \\
\text { asset at the end of the contract) }\end{array}$ & $\begin{array}{l}\text { The service is } \\
\text { indispensable } \\
\text { The service is } \\
\text { not indispensable }\end{array}$ & Public \\
\hline $\begin{array}{l}\text { Private information of } \\
\text { the government (with } \\
\text { perception bias by the } \\
\text { firm) }\end{array}$ & & & 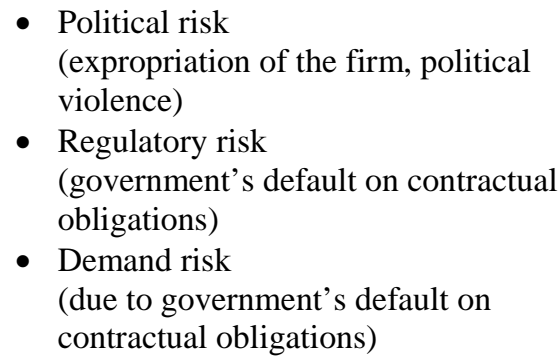 & $\begin{array}{l}\text { Strong } \\
\text { regulatory } \\
\text { body } \\
\text { Weak } \\
\text { regulatory } \\
\text { body }\end{array}$ & Public \\
\hline
\end{tabular}




\section{CONCLUSiOnS}

The rise of PPPs in the United States (including the innovative and massive PPIP) and elsewhere has been remarkable. It led to major successes and, with the value of the long-term projects currently being procured in the United States in the transportation sector alone reaching several billion dollars (and individually ranging from a few hundred million dollars to a few billion dollars), the benefits are potentially tremendous for the states and the local authorities involved. Understandably they would like to increase the leverage of taxpayer money to attract more private funds in order to undertake their infrastructure projects. Yet, PPPs also involve risks that need to be carefully assessed. With its advantages, but also its limits, the P-A framework provides a useful tool to do so. We have argued that there are two distinct sources of risks: the risks that are intrinsic to the project, and those associated with the specific PPP contract arrangements, in particular with the "vertical" nature of the partnership between the principal (the public sector) and the agent (the private company). We have shown that the latter is often neglected in typologies of risks. Hence, our typology separates "project” and "partnership."

We are aware that our typology does not answer all questions related to risks (by nature, typologies never do), but it helps raise a certain number of critical issues in PPPs, in particular: the optimal allocation of noninsurable risks between the government and the private sector firm; and how the risk-aversion of the principal and the agent should affect the design of the optimal contract. Some other issues are not addressed because they may not require the use of a typology. For example, the absence of a single accounting framework for PPPs clearly presents a danger for both parties. On the other hand, we have shown that an important dimension of risk had its root in the asymmetry of information between the partners, and this dimension was relevant to both the partnership and the project. But while the principal-agent model only allows for the agent to be better informed than its principal, we have stressed the case where the principal can hold more information than the agent on certain aspects of the project.

We have also emphasized the perception bias as a critical factor in the behavior of the players, and this bias is exacerbated by their conflicting incentives. These biases may explain, for example, why a project could be (rationally) undertaken under a PPP arrangement, but face opposition from the public. This could be because the general public has access to some specific information, but also because it is influenced by its own biased views on the probabilities for certain key variables (the intensity of the demand, for example). In addition, competition between private sector operators interested in the PPP could imply that there will be some secrecy, and this could reinforce perception biases. This is why, although we are strong supporters of transparency, in particular of fiscal transparency, we acknowledge that perception bias also affects risks and one of them (faced mostly by the public sector) is the reaction of the public, even if all information related to the contract is released and scrutinized, but misread. 


\section{REFERENCES}

Akintoye, Akintola, Matthias Beck, and Cliff Hardcastle, 2003, Public-Private Partnerships: Managing risks and opportunities (Wiley-Blackwell).

Arthur Andersen and Enterprise LSE, 2000, Value for Money Drivers in the Private Finance Initiative, Report Commissioned by the Treasury Taskforce on PPI (London: Office of Government Commerce).

Benett, John, and Elisabetta Iossa, 2006, "Building and Managing Facilities for Public Services,” Journal of Public Economics, Vol. 90, pp. 2143-60.

Bentz, Andreas, Paul A. Grout and Maija Halonen-Akatwijuka, 2001, "What Should the State Buy?" CMPO Working Paper Series No. 01/40 (University of Bristol: Centre for Market and Public Organisation).

Best, Jacqueline, 2005, The Limits of Transparency: Ambiguity and the History of International Finance (Ithaca, New York: Cornell University Press).

Coase, Ronald, 1937, "The Nature of the Firm", Economica, Vol. 4, No. 16, pp. 386-405. 1992, "The Institutional Structure of Production," The American Economic Review, Vol. 82, No 4, pp. 713-19.

Cuttaree, Vickram, 2008, “Successes and Failures in PPP Projects,” mimeo, Europe and Central Asia Region (Washington: World Bank).

de Palma, André, Luc Leruth, and Guillaume Prunier (forthcoming). "Risks in PrincipalAgent Relationships” (Paris: Ecole Normale Supérieure de Cachan).

de Palma, André, and Jean-Luc Prigent, 2008, "Hedging Global Environment Risks: An Option-Based Portfolio Insurance,” Automatica, Vol. 44, No. 6, pp. 1519-31.

Demsetz, Harold, 1967, "Toward a Theory of Property Rights," The American Economic Review Papers and Proceedings, Vol. 57, No. 2, pp. 347-59.

Dewatripont, Mathias and Patrick Legros, 2005, "Public-Private Partnerships: Contract Design and Risk Transfer,” European Investment Bank Papers, Vol. 10, No. 1, pp. 120-45.

Economic Commission, 2004, “Green Paper on Public-Private Partnerships and Community Law on Public Contracts and Concessions,” EC-COM-327 (Brussels).

Estache, Antonio, 2005,. "PPI Partnerships Versus PPI Divorces in Developing Countries (or Are We Switching From PPPI to PPDI?),” Policy Research Working Paper No. 3470 (Washington: World Bank). 
European Investment Bank Synthesis Report, 2005, "Evaluation of PPP Projects Financed by the EIB.” Available at http://www.bei.europa.eu/projects/publications/evaluation-ofppp-projects-financed-by-the-eib.htm.

Fitzgerald, Peter, 2004, "Review of Partnerships Victoria Provided Infrastructure, Final Report to the Treasurer," (Melbourne: Growth Solutions Group). Available at http://www.partnerships.vic.gov.au/CA25708500035EB6/WebObj/PPPFinalFitzgeral dJan2004Review/\$File/PPP\%20Final\%20Fitzgerald\%20\%20Jan\%202004Review.pdf

France, Direction Générale des Routes, 2005, December Report, p. 30. Available at http://www.equipement.gouv.fr/IMG/pdf/texte_cle283671.pdf.

Furman, Jason and Joseph E. Stiglitz, 1998, “Economic Crises: Evidence and Insights from East Asia.” Brookings Papers on Economic Activity, Vol. 1998, No. 2, pp. 1-135.

Gilroy, Leonard, 2008, "Public-Private Partnerships in Transportation: Opportunities for Massachusetts,” Testimony to the Massachusetts Joint Committee on Transportation (Callifornia: Reason Foundation).

— Roads Through Public-Private Partnerships: Frequently Asked Questions,” Policy Brief No 58 (California: Reason Foundation).

Hart, Olivier, 2003, “Incomplete Contracts and Public Ownership: Remarks, and an Application to Public-Private Partnerships” Economic Journal, Vol. 113. pp. 69-76

- Andrei Shleifer, and Robert W. Vishny, 1997, "The Proper Scope of Government: Theory and An Application to Prisons,” Quarterly Journal of Economics, Vol. 112, pp. 1127-62.

Hemming, and others, 2006, Public-Private Partnerships, Government Guarantees, and Fiscal Risk (Washington: International Monetary Fund).

International Monetary Fund, 2004, "Public-Private Partnerships,” (March) (Washington). Available at http://www.imf.org/external/np/fad/2004/pifp/eng/031204.htm.

Irwin, Timothy, 1998, “Contingent Liabilities-A Threat to Fiscal Stability,” World Bank Poverty Research and Expenditure Management (PREM) Note No. 9 (Washington: World Bank).

_, 2004 , "Public Money for Private Infrastructure: Deciding When to Offer Guarantees, Output-Based Subsidies, and Other Fiscal Support,” World Bank Working Paper No. 26601 (Washington: World Bank).

International Journal of Industrial Organization, Special Issue (2008), Vol. 26, No. 2.

Kahneman, Daniel, and Amos Tversky, 1979, "Prospect Theory: An Analysis of Decisions Under Risk,” Econometrica, Vol. 47, No. 2, pp. 263-92. 
Kofman, Fred, and Jacques Lawarrée, 1993, "Collusion in Hierarchical Agency," Econometrica, Vol. 61, No. 3, pp. 629-56.

1996, “On the Optimality of Allowing Collusion,” Journal of Public Economics, Vol. 61, No. 3, pp. 383-407.

Laffont, Jean-Jacques, and Jean Tirole, 1993, A Theory of Incentives in Procurement and Regulation, (Cambridge, Massachussets: MIT Press).

Leruth, Luc, 2009, "Public-private Cooperation in Infrastructure Development: A Story of Contingent Liabilities, Fiscal Risks, and Other (Un)pleasant Surprises,” forthcoming in Networks and Spatial Economics.

Lichtenstein, and others, 1978, "Judged Frequency of Lethal Events," Journal of Experimental Psychology: Human Learning and Memory, Vol. 4, No. 6, pp. 551-78.

Martimort, David, and Jérôme Pouyet, 2008, “To Build or Not To Build : Normative and Positive Theories of Public-Private Partnerships,” International Journal of Industrial Organisation, Vol. 26, No. 2, pp. 393-411.

Olson, Mancur, 1965, The Logic of Collective Action: Public Goods and the Theory of Groups, (Boston, Massachusetts: Harvard University Press, 2nd ed.).

Partnerships Victoria, 2004, "Review of Partnerships Victoria Provided Infrastructure: Final Report to the Treasurer” (January). Available at http://www.partnerships.vic.gov.au.

Polackova, Hana, 1998, “Government Contingent Liabilities: A Hidden Risk to Fiscal Stability,” World Bank Policy Research Working Paper No. 1989 (Washington: World Bank).

PriceWaterHouseCoopers, 2005, "Delivering the PPP Promise: A review of PPP issues and activity" (December). Available at www.pwc.ch/user content/editor/files/publ public/pwc ppp delivering_promise e.p df.

Schwartz, Gerd, Ana Corbacho, and Katja Funke, 2008, Public Investment and PublicPrivate Partnerships: Addressing Infrastructure Challenges and Managing Fiscal Risks (Washington: International Monetary Fund).

Stark, Roger D., 2008, “Current Developments in U.S. PPPs,” paper presented at the World Bank Conference on Public-Private Partnerships in Infrastructure: International Best Practice and Regional Application (Central Europe and Baltic Countries), Washington D.C., December.

Tirole, Jean, and Eric S. Maskin, 2008, "Public-Private Partnerships and Government Spending Limits,” International Journal of Industrial Organization, Special Issue, Vol. 26, No. 2, pp. 412-20. 
United Kingdom, National Audit Office Report, 2000, The Financial Analysis for the London Underground Public-Private Partnerships (London)

— , 2003, The Operational Performance of PFI Prisons (London).

—

_ 2006, Value-for-Money Assessment Guidance. Available at http://www.hmtreasury.gov.uk/d/vfm_assessmentguidance061006opt.pdf (London: HM Treasury).

United States, Department of Transportation, 2004, "Report to Congress on PPPs" (Washington).

_ 2008, "Innovation Wave: an Update on the Burgeoning Private Sector role in U.S. Highway and Transit Infrastructure” (Washington).

— 2009, "Public Policy Considerations in Public-Private Partnership (PPP) Arrangements" (Washington).

United States, Department of the Treasury, 2009, “Treasury Announces Receipt of Applications to Become Fund Managers under Public Private Investment Program.” Available at http://www.financialstability.gov/roadtostability/publicprivatefund.html.

United States, Government Accountability Office, 2007, High-Risk Series: An Update (GAO-07-310) (Washington).

Välilä, Timo, 2005, "How Expensive are Cost Savings? On the Economics of Public-Private Partnerships,” European Investment Bank Papers, Vol. 10, No. 1, pp. 94-119.

—- Tomasz Kozluk, and Aaron Mehrotra, 2005, in European Investment Bank Papers, Vol. 10, No. 1, pp. 18-38.

Vickerman, Roger, 2004, "Private Sector Finance of Transport Infrastructure: Progress and Prospects.” paper prepared for the STELLA Focus Group 5 Synthesis Meeting. Athens, June.

Williamson, Oliver, 2002, "The Theory of the Firm as Governance Structure: From Choice to Contract," Journal of Economic Perspectives, Vol. 16, No. 3, pp. 171-95. 